\title{
Influence of dietary probiotic inclusion on growth performance, nutrient utilization, ruminal fermentation activities and methane production in growing lambs
}

Ayman Hassan, Hany Gado, Uchenna Y. Anele, Maria A. M. Berasain \& Abdelfattah Z. M. Salem

To cite this article: Ayman Hassan, Hany Gado, Uchenna Y. Anele, Maria A. M. Berasain \& Abdelfattah Z. M. Salem (2019): Influence of dietary probiotic inclusion on growth performance, nutrient utilization, ruminal fermentation activities and methane production in growing lambs, Animal Biotechnology, DOI: 10.1080/10495398.2019.1604380

To link to this article: https://doi.org/10.1080/10495398.2019.1604380

曲 Published online: 21 Apr 2019.

Submit your article to this journal

View Crossmark data $\nearrow$ 


\title{
Influence of dietary probiotic inclusion on growth performance, nutrient utilization, ruminal fermentation activities and methane production in growing lambs
}

\author{
Ayman Hassan $^{a}$, Hany Gado ${ }^{b}$, Uchenna Y. Anele ${ }^{c}$, Maria A. M. Berasain ${ }^{d}$, and Abdelfattah Z. M. Salem ${ }^{d}$ (D) \\ ${ }^{\mathrm{a}}$ Animal Production Research Institute, Agriculture Research Center, Cairo, Egypt; ${ }^{\mathrm{b}}$ Department of Animal Productions, Faculty of \\ Agriculture, Ain Shams University, Cairo, Egypt; ${ }^{C}$ North Carolina Agricultural and Technical State University, Greensboro, NC, USA; \\ ${ }^{d}$ Facultad de Medicina Veterinaria y Zootecnia, Universidad Autónoma del Estado de México, Toluca, México
}

\begin{abstract}
The use of two probiotic products as a means of improving in vitro and ruminal dry matter digestibility, fermentation characteristics and growth performance of Barki lambs were evaluated. The probiotic products in powder (PP) or liquid (PL) forms were produced from Ruminococcus flavefaciens, through an anaerobic fermentation process. Barki lambs $(n=30$; $24.5 \pm 0.5 \mathrm{~kg}$ body weight) were used in a completely randomized block design and randomly assigned among three experimental groups and fed for 75 days. Lambs were fed an equal amount of concentrate feed mixture with either no probiotic product (control), or with $20 \mathrm{~g}$ of $\mathrm{PP}$, or $10 \mathrm{ml}$ of $\mathrm{PL}$ per animal/d, with rice straw ad libitum. Both $\mathrm{PP}$ and $\mathrm{PL}$ treatments resulted in an increase $(p<0.05)$ in nearly all of the digestibility coefficients, nitrogen utilization, cell wall constituents, total volatile fatty acids, rumen volume, microbial nitrogen synthesis, gas production and average daily gain compared to the control group. Ruminal ammonia nitrogen, acetic acid and in vitro methane concentrations and protozoa count decreased $(p<0.03)$ in the treatment groups. Overall, the probiotic in a powder or liquid form increased in vitro dry matter digestibility, improved lambs daily gain and nutrient digestibility.
\end{abstract}

\section{KEYWORDS}

Probiotic; performance; methane; ruminal fermentation

\section{Introduction}

The use of probiotics (direct-fed microbials) as ruminant feed additives can improve dry matter intake, fiber digestibility and growth performance. ${ }^{1,2}$ Probiotics are non-pathogenic living microorganisms that have been shown to produce no drug resistance or drug residues when fed to animals. Probiotics have the potential to be used in place of antibiotics and have been widely used in the food and feed industries during the past few decades. ${ }^{3}$ Overall, results from using feed additives have been mixed and are thought to be partially due to enzyme characteristics, composition of the target forage, and ruminal conditions (temperature and $\mathrm{pH}$ ); thus, feed additive selection should first be tested in a ruminal environment. ${ }^{4}$ Numerous probiotic products are commercially available for ruminants, especially for dairy cows. These products are either of bacterial or yeast (fungi) origin and responses attributed to yeast probiotics, are usually related to stimulation of cellulolytic and lactate-utilizing bacteria in the rumen. ${ }^{3}$

There is interest in enhancing the nutritive value of poor quality forages, especially when harvested at an advanced stage of maturity ( $>500 \mathrm{~g}$ NDF; $>400 \mathrm{~g}$ $\mathrm{ADF})$. Rice straw has very low crude protein concentration, less palatability and low organic matter degradation. Increasing the digestibility of low quality feeds using enzyme technologies has resulted in improvements in ruminant performance. Beauchemin et al. $^{5}$ reported that adding enzymes to animal diets increases the overall hydrolytic capacity of the rumen. Colombatto et al. ${ }^{4}$ reported that exogenous enzymes increased microbial attachment to diets and increased total number of viable rumen bacteria. The beneficial impact of the addition of exogenous enzymes depends on several factors such as type of enzyme preparation, specific enzyme activities, enzyme stability, amount of enzyme added, diet composition and application 
method. ${ }^{6}$ Studies have shown that probiotics can enhance feed efficiency and daily weight gain of feedlot cattle and health performance of neonates. ${ }^{7,8}$ Probiotics are utilized in the feedlot to maintain gut health and improve feed efficiency by increasing the absorption rate of volatile fatty acids and lactate produced. ${ }^{8}$ There is limited information on using probiotics to improve fiber digestibility of low-quality crop residues.

Probiotic products produced from anaerobic fermentation of Ruminococcus flavefaciens, has shown to improve live weight gain and feed conversion of wheat straw in sheep and goats. ${ }^{9}$ It has also shown to improve nutrients digestibility and ruminal fermentation of cows fed diets containing Egyptian by-product feeds. ${ }^{1}$ A previous report noted that yeast probiotics favor the proliferation of rumen fungi population by increasing the supply of vitamin $B_{1}$ to these microbes. ${ }^{10}$ They also stimulate activities of fibrolytic bacteria with concomitant increase in fiber degradation by scavenging oxygen to make an anaerobic condition conducive for cellulolytic bacteria. The main actions of the probiotics are on rumen kinetics and improvements on microflora effectiveness in utilizing the feed ingredients that usually reflects on animal performance. ${ }^{1}$ Thus, the objective of this study was to evaluate the feasibility of using the probiotics in two forms (powder and liquid) to improve growth performance, nutrients digestibility and ruminal fermentation of Barki lambs.

\section{Materials and methods}

Three trials were used to evaluate the use of probiotics (direct-fed microbial) as a potential means of improving growth performance and ruminal digestion, fermentation, and gas production characteristics.

\section{Trial 1}

Thirty weaned Barki male lambs between 6 and 8 months of age $(24.5 \pm 0.15 \mathrm{~kg}$ body weight $)$ were used in a completely randomized block design. After 2 weeks of adaptation, where lambs consumed a ration of concentrate feed mixture plus rice straw, lambs were weighed and randomly divided into three equal groups (10 lambs/each) and then randomly distributed into individual cages according to their assigned treatment. All lambs were fed an equal amount of concentrate feed mixture with or without the probiotic products, and fed on rice straw ad libitum (Table 1). Animals were randomly assigned to one of three experimental treatments: control and two probiotic
Table 1. Chemical composition $(\mathrm{g} / \mathrm{kg}$, DM basis) of the concentrate feed mixture and rice straw. ${ }^{\text {a }}$

\begin{tabular}{|c|c|c|}
\hline & $\begin{array}{l}\text { Concentrate feed } \\
\text { mixture }\end{array}$ & $\begin{array}{l}\text { Rice } \\
\text { straw }\end{array}$ \\
\hline \multicolumn{3}{|l|}{ Ingredients } \\
\hline Corn grain, ground & 412 & \\
\hline Wheat bran & 128 & \\
\hline Barley grain, ground & 113 & \\
\hline Soybean meal & 234 & \\
\hline Corn gluten & 39 & \\
\hline Molasses & 44 & \\
\hline Calcium carbonate & 10 & \\
\hline Dicalcium phosphate & 10 & \\
\hline Common salt $(\mathrm{NaCl})$ & 5 & \\
\hline Mineral and Vitamin premix ${ }^{a}$ & 5 & \\
\hline \multicolumn{3}{|c|}{$\begin{array}{l}\text { Chemical composition of concentrates and hay ( } \mathrm{g} / \mathrm{kg} \text {, dry } \\
\text { matter basis) }\end{array}$} \\
\hline Organic matter & 935 & 906 \\
\hline Crude protein & 139 & 37 \\
\hline Ether extract & 27 & 10 \\
\hline Nitrogen free extract & 700 & 462 \\
\hline Neutral detergent fiber & 367 & 732 \\
\hline Acid detergent fiber & 257 & 499 \\
\hline Acid detergent lignin & 43 & 105 \\
\hline Acid detergent insoluble crude protein & 14 & 75 \\
\hline Hemicellulose & 110 & 233 \\
\hline Cellulose & 214 & 394 \\
\hline
\end{tabular}

products supplementation for $75 \mathrm{~d}$. All lambs were fed the basal diet and without the probiotics product preparation (control) and the other two treatments received $20 \mathrm{~g} / \mathrm{animal} / \mathrm{d}$ of probiotics product in powder form (i.e., PP) and $10 \mathrm{ml} /$ animal/day of probiotics product preparation in liquid form (i.e., PL), respectively. The probiotics product was manually mixed with the diet before the morning feeding. Feed intake was recorded daily and lambs body weight was recorded weekly until day 75 . Average daily gain was calculated as the difference between two successive weights divided by the time period (days). Lambs were vaccinated against pneumonia (Pneumococcal polysaccharide vaccine protects against 23 types of pneumococcal bacteria), injected with a broad-spectrum antibiotic of amoxicillin, and drenched a broad spectrum anthelmintic (Ivomec).

The probiotics product in powder (PP) or liquid (PL) forms were produced from Ruminococcus flavefaciens, obtained through an anaerobic fermentation process. The PP was $0.28 \times 1014 \mathrm{CFU}$ with one gram of PP/gram of corn flour and PL was $1.1 \times 1013$ $\mathrm{CFU}$ with one gram of $\mathrm{PL} / \mathrm{ml}$ of water. Furthermore, the PL is a biotechnical solution product made from natural sources to elevate the level of cellulase from anaerobic bacteria and contained specific enzymes such as cellulase (7.1 IU), hemicellulase $(2.3 \mathrm{IU} / \mathrm{mg})$, 
amylase (61.5 IU) and protease (29.2 IU) per $\mathrm{ml}$ or gram. The PP is a biotechnical powder product containing similar enzymes as PL but also Saccharomyces cerevisiae yeast.

\section{Trial 2}

Digestibility and nitrogen balance trials were carried out using nine Barki rams $(52.3 \pm 1.4 \mathrm{~kg} ; 3 \mathrm{rams} /$ treatment). Sheep were fed twice daily according to $\mathrm{NRC}^{11}$ at 0800 and 1500, and water was offered ab libitum. Rams were fed on the rations for two weeks served as the adaptation period followed by 7 days of total feces and urine collection. Animals were placed in individual metabolic cages for feces and urine collection and daily feces and urine from each ram was collected and weighed in the morning before feeding. Approximately $10 \mathrm{~g} / \mathrm{kg}$ of the daily feces from each ram was sampled after thorough mixing and frozen until subsequent analysis. A $15 \mathrm{ml}$ urine sample was collected and mixed with $40 \mathrm{ml}$ of $100 \mathrm{ml} / \mathrm{l}$ of $\mathrm{HCl}$ to keep the final $\mathrm{pH}$ below 3. Urine samples were stored at $-18^{\circ} \mathrm{C}$ until taken for nitrogen analyses. Subsamples $(0.20$ of total collected) of feces and urine were taken once daily then stored at $-18^{\circ} \mathrm{C}$ until analyses. Fecal samples were dried at $60^{\circ} \mathrm{C}$ for $72 \mathrm{~h}$.

Samples of feed, orts and feces were ground through 1-mm screen (Wiley mill, Arthur H. Thomas Co., Philadelphia, PA) and a sample of $50 \mathrm{~g} /$ ration per sheep was analyzed according to AOAC. ${ }^{12}$ Samples were analyzed for dry matter (DM, method 934.01), ash (method 942.05), nitrogen (N, method 954.01) and ether extract (EE, method 920.39). The neutral detergent fiber (NDF, Van Soest et al. ${ }^{13}$ ), acid detergent fiber (ADF) and lignin (method 973.18) analyses used was sequentially done using an ANKOM 200 fiber analyzer unit (ANKOM Technology Corporation, Fairport, NY, USA). Neutral detergent fiber was assayed without use of an alpha amylase but with sodium sulfite. Both NDF and ADF are expressed with residual ash. Hemicellulose was calculated by the difference between NDF and ADF, while the cellulose was calculated by difference between $\mathrm{ADF}$, lignin concentrations. ${ }^{14}$ Urine samples were analyzed for $\mathrm{N}$ according to AOAC (Table 1). ${ }^{12}$

Rumen liquor samples were taken at $0,1,3$ and $6 \mathrm{~h}$ after feeding in the morning from three fistulated Barki ewes ( $48.0 \pm 0.8 \mathrm{~kg}$ body weight) for each ration. Ewes fed on the treatment diets for 15 days as adaptation period and then followed by two consecutive days for ruminal sampling. The $\mathrm{pH}$ of the rumen fluid was measured immediately using an Orian 680 digital
$\mathrm{pH}$ meter and the remaining fluid was strained through four layers of chesses cloth at each sampling time for other analyses. Rumen fluid $\mathrm{NH}_{3}-\mathrm{N}$ was determined by using $\mathrm{MgO}$ as described by Al-Rabbat et al. ${ }^{15}$. Total volatile fatty acid concentration was estimated by using steam distillation as described by Warner. ${ }^{16}$ Microbial protein synthesized (g of microbial protein/day) in the rumen of goats fed the treatment diets were calculated using the equation developed by Borhami et al. ${ }^{17}$ :

$$
\begin{aligned}
& \text { Microbial protein } \mathrm{g} / \text { day } \\
& =\text { mole VFA produced/day } \times 2 \times 13.48 \\
& \quad \times 10.5 \times 6.25 / 100,
\end{aligned}
$$

where one mole of VFA yields about 2 mole ATP, ${ }^{18}$ one mole ATP produces 13.48 Yield ATP ( $\mathrm{g}$ of DM microbial cell), and percentage of $\mathrm{N}$ of dry microbial cell $=10.5 .^{19}$

\section{Trial 3}

Gas production was measured using an adaptation of the technique described by Theodorou et al. ${ }^{20}$ The same diet used during the in vivo experiment $(600 \mathrm{~g}$ concentrate feed and $400 \mathrm{~g}$ of rice straw) was formulated in triplicates for the in vitro evaluation.

One gram of the ground samples, of each triplicate diet samples, without or with the addition of $\mathrm{PP}$ $(20 \mathrm{mg})$ or PL $(10 \mu \mathrm{l})$ were incubated in $120-\mathrm{mL}$ serum bottles (4 bottles per diet sample) with $50 \mathrm{ml}$ of diluted rumen fluid $(10 \mathrm{~mL}$ mixed rumen fluid + $40 \mathrm{~mL}$ medium prepared under continuous flushing with $\mathrm{CO}_{2}$; Theodorou et al. ${ }^{20}$ Incubations, for each diet, were performed in three 24 -h runs using rumen fluid mixed from the three fistulated sheep on different weeks of incubation, with 4 blank bottles per run. The blank bottles containing only diluted rumen fluid were used to compensate for gas production in the absence of substrate. All bottles were closed with rubber stoppers, crimped with aluminum seals, shaken and placed in an incubator at $39^{\circ} \mathrm{C}$. The volume of gas produced in each bottle was recorded after $24 \mathrm{~h}$ using a pressure transducer (Delta Ohm DTP704-2BGI, Herter Instruments SL, Barcelona). A 10-ml gas sample was collected into vacuum tubes and stored until analyzed for $\mathrm{CH}_{4}$ concentration by gas chromatography.

Total protozoa counts were determined according to the method of Dehority. ${ }^{21}$ Two $\mathrm{mL}$ of rumen fluid was pipetted into a screw-capped test tube and $10 \mathrm{ml}$ of formalinized physiological saline $(20 \mathrm{ml}$ formaldehyde in $100 \mathrm{ml}$ saline $(0.85 \mathrm{~g}$ sodium chloride in $100 \mathrm{ml}$ distilled water)) added. Two drops of Lugol's 
iodine were added to the test tube that was then mixed thoroughly and stood overnight at room temperature. Total counts of protozoa were made in 30 microscopic fields at a magnification of $200 \times$ in a Haemocytometer (Neubauer improved, Marienfeld, Germany).

\section{Statistical analysis}

Data of each experiment (Trials 1, 2 and 3) was statistically analyzed as a completely randomized design using the PROC MIXED procedure of SAS. ${ }^{22}$ In Trials 1 and 2, the experimental unit was the animal. In Trial 3, data of each one of the 3 runs within the same diet sample, with or without the probiotic product were averaged and used as an experimental unit. ${ }^{23}$ The following statistical model was used for the three trials:

$$
Y i j=\mu+D i+e i j
$$

where

$Y i j=$ observation on experimental unit

$\mu=$ overall mean

$D i=$ effect of enzyme

$e i j=$ random error

Tukey's test was used for the multiple comparisons among mean values for different treatments.

\section{Results}

\section{Nutrient digestibility study}

Results showed increased total DM intake $(p=0.02)$ for lambs fed the probiotics product diets versus lambs fed the control diet (Table 2). Digestibility coefficients of nutrients were greater $(p<0.05)$ in lambs supplemented with probiotics than those on the control diet. Similarly, nitrogen was efficiently utilized in the probiotics treated lambs. Approximately 0.52 of ingested nitrogen was retained in the treatment group compared with the control group (0.40). There were no differences $(p<0.05)$ in $\mathrm{pH}$ values between treatments (Table 3). Ammonia-nitrogen was reduced $(p=0.03)$ in lambs supplemented with probiotics. Lambs fed diets supplemented with PP or PL had the highest TVFA, propionate and acetate:propionate. The PP or PL increased TVFA by 22 and 25\%, and propionate by 3.9 , and $4.0 \%$, respectively. Rumen microbial $\mathrm{N}$ synthesis of sheep was improved by feeding PP or PL.

\section{Performance study}

The results of the initial and final body weight, average daily gain, G:F, and economic efficiency are presented in Table 4. All performance variables were

Table 2. Effects of probiotic additives on dry matter intake, nutrient digestibility, nutritive value, and nitrogen utilization of male barki sheep.

\begin{tabular}{|c|c|c|c|c|c|}
\hline & \multicolumn{5}{|c|}{ Treatment $^{1}$} \\
\hline & Control & PP & PL & $\mathrm{SEM}^{2}$ & $p$-Value \\
\hline \multicolumn{6}{|l|}{ Dry matter intake, kg } \\
\hline Concentrate & 0.81 & 0.81 & 0.81 & & \\
\hline Rice straw & 0.37 & 0.42 & $0.42^{\mathrm{a}}$ & 0.03 & 0.67 \\
\hline Total Dry matter intake & $1.18^{\mathrm{b}}$ & $1.23^{\mathrm{a}}$ & $1.23^{\mathrm{a}}$ & 0.02 & 0.02 \\
\hline \multicolumn{6}{|c|}{ Digestibility coefficients ( $\mathrm{g}$ digested $/ \mathrm{g}$ ingested) } \\
\hline Dry matter & $0.62^{\mathrm{b}}$ & $0.64^{\mathrm{a}}$ & $0.65^{\mathrm{a}}$ & 0.001 & 0.01 \\
\hline Organic matter & $0.65^{\mathrm{b}}$ & $0.66^{\mathrm{a}}$ & $0.67^{\mathrm{a}}$ & 0.073 & 0.01 \\
\hline Crude protein & $0.62^{\mathrm{b}}$ & $0.65^{\mathrm{a}}$ & $0.65^{\mathrm{a}}$ & 0.052 & 0.01 \\
\hline Ether extract & $0.69^{\mathrm{b}}$ & $71.4^{\mathrm{a}}$ & $0.72^{\mathrm{a}}$ & 0.032 & 0.02 \\
\hline Neutral detergent fiber & $0.55^{\mathrm{b}}$ & $0.59^{\mathrm{a}}$ & $0.59^{\mathrm{a}}$ & 0.043 & 0.01 \\
\hline Neutral detergent fiber & $0.52^{\mathrm{b}}$ & $0.54^{\mathrm{a}}$ & $0.54^{\mathrm{a}}$ & 0.031 & 0.02 \\
\hline Acid detergent lignin & $0.41^{\mathrm{b}}$ & $0.43^{\mathrm{a}}$ & $0.43^{\mathrm{a}}$ & 0.033 & 0.02 \\
\hline \multicolumn{6}{|l|}{ Nutritive value, $\mathrm{g} / \mathrm{kg}$ intake } \\
\hline Total digestible nutrients & $615^{\mathrm{b}}$ & $632^{\mathrm{a}}$ & $637^{\mathrm{a}}$ & 15.1 & 0.02 \\
\hline Digestible crude protein & 66 & 67 & 67 & 6.3 & 0.85 \\
\hline \multicolumn{6}{|l|}{ Nitrogen utilization } \\
\hline $\mathrm{N}$ intake, $\mathrm{g} / \mathrm{d}$ & $20.3^{\mathrm{b}}$ & $20.5^{\mathrm{a}}$ & $20.5^{\mathrm{a}}$ & 0.1 & 0.01 \\
\hline $\mathrm{N}$ absorbed, $\mathrm{g} / \mathrm{d}$ & $12.5^{\mathrm{b}}$ & $13.2^{\mathrm{a}}$ & $13.2^{\mathrm{a}}$ & 0.2 & 0.01 \\
\hline $\mathrm{N}$ retained, $\mathrm{g} / \mathrm{d}$ & $4.9^{\mathrm{b}}$ & $6.7^{\mathrm{a}}$ & $7.0^{\mathrm{a}}$ & 0.3 & 0.02 \\
\hline $\mathrm{N}$ retained, fraction of $\mathrm{N}$-intake & $0.24^{\mathrm{b}}$ & $0.33^{\mathrm{a}}$ & $0.34^{\mathrm{a}}$ & 0.903 & 0.03 \\
\hline $\mathrm{N}$ retained, fraction of $\mathrm{N}$-absorbed & $0.40^{\mathrm{b}}$ & $0.51^{\mathrm{a}}$ & $0.53^{\mathrm{a}}$ & 0.101 & 0.04 \\
\hline
\end{tabular}


Table 3. Effects of probiotic additives on ruminal fermentation activities and microbial protein synthesis of fistulated barki ewes.

\begin{tabular}{|c|c|c|c|c|c|}
\hline & \multicolumn{3}{|c|}{ Treatment $^{1}$} & \multirow[b]{2}{*}{ SEM $^{2}$} & \multirow[b]{2}{*}{$p$-Value } \\
\hline & Control & PP & PL & & \\
\hline $\mathrm{pH}$ & 6.44 & 6.51 & 6.49 & 1.11 & 0.63 \\
\hline $\mathrm{NH}_{3}-\mathrm{N}, \mathrm{mg} / 100 \mathrm{ml}$ & $15.1^{\mathrm{a}}$ & $14.1^{\mathrm{b}}$ & $14.0^{\mathrm{b}}$ & 1.23 & 0.03 \\
\hline VFA, meq/100 ml & $9.3^{\mathrm{b}}$ & $11.3^{\mathrm{a}}$ & $11.6^{\mathrm{a}}$ & 1.31 & 0.02 \\
\hline \multicolumn{6}{|l|}{ Molar proportion } \\
\hline Acetic acid & $0.58^{\mathrm{a}}$ & $0.57^{\mathrm{b}}$ & $0.56^{\mathrm{b}}$ & 0.023 & 0.03 \\
\hline Propionic acid & $0.25^{\mathrm{b}}$ & $0.26^{\mathrm{a}}$ & $0.26^{\mathrm{a}}$ & 0.014 & 0.03 \\
\hline Butyric acid & $0.10^{\mathrm{a}}$ & $0.08^{\mathrm{b}}$ & $0.08^{\mathrm{b}}$ & 0.003 & 0.03 \\
\hline Acetic:Propionic & $2.2^{\mathrm{b}}$ & $2.3^{\mathrm{ab}}$ & $2.4^{\mathrm{a}}$ & 0.12 & 0.04 \\
\hline Rumen volume, L & $3.05^{\mathrm{b}}$ & $3.24^{\mathrm{a}}$ & $3.26^{\mathrm{a}}$ & 0.090 & 0.04 \\
\hline Rate of out flow, /h & $0.063^{a}$ & $0.061^{b}$ & $0.061^{b}$ & 0.0007 & 0.04 \\
\hline Microbial nitrogen yield, $\mathrm{g} / \mathrm{d}$ & $12.3^{\mathrm{b}}$ & $13.8^{\mathrm{a}}$ & $13.5^{\mathrm{a}}$ & 0.22 & 0.03 \\
\hline $\begin{array}{l}\mathrm{a}, \mathrm{b} \text { Means in the same row } \\
\text { ent }(p<0.05) \text {. }\end{array}$ & with di & ifferent & superscrip & ts were & differ- \\
\hline \multicolumn{6}{|c|}{$\begin{array}{l}{ }^{1} \text { Control (lambs were fed } 600 \mathrm{~g} \text { of a concentrate feed mixture plus } 400 \mathrm{~g} \\
\text { of rice straw per } \mathrm{kg} \text { of DM without any probiotic); PP (control diet sup- } \\
\text { plemented with } 20 \mathrm{~g} \text { of the probiotic in powder form per animal/day); } \\
\text { and PL (control diet supplemented with } 10 \mathrm{ml} \text { of the probiotic in liquid } \\
\text { form per animal/day) in a completely randomized block design. } \\
{ }^{2} \mathrm{SEM} \text { : greatest standard error of the mean. }\end{array}$} \\
\hline
\end{tabular}

Table 4. Effects of probiotic additives on growth performance and economic efficiency of male barki lambs.

\begin{tabular}{|c|c|c|c|c|c|}
\hline & \multicolumn{3}{|c|}{ Treatment $^{1}$} & \multirow{2}{*}{\multicolumn{2}{|c|}{ SEM $^{2} p$-Value }} \\
\hline & Control & PP & PL & & \\
\hline Initial body weight, kg & 24.5 & 24.6 & 24.4 & 1.91 & 0.75 \\
\hline Final body weight, kg & $33.9^{\mathrm{b}}$ & $35.9^{a}$ & $36.4^{\mathrm{a}}$ & 1.72 & 0.02 \\
\hline Total gain $(\mathrm{G}), \mathrm{kg}$ & $9.4^{b}$ & $11.8^{\mathrm{a}}$ & $12.5^{\mathrm{a}}$ & 0.44 & 0.01 \\
\hline Average daily gain, g/day & $125.3^{c}$ & $157.2^{\mathrm{b}}$ & $166.9^{\mathrm{a}}$ & $1.41<$ & $<0.001$ \\
\hline Dry matter intake (F), kg/day & $1.06^{\mathrm{c}}$ & $1.18^{\mathrm{b}}$ & $1.19^{\mathrm{a}}$ & 0.025 & 0.009 \\
\hline $\mathrm{G}: \mathrm{F}$ & $0.118^{c}$ & $0.133^{b}$ & $0.140^{\mathrm{a}}$ & 0.01 & 0.002 \\
\hline \multicolumn{6}{|l|}{ Economic efficiency ${ }^{3}$} \\
\hline Average daily feed cost, L.E & 2.15 & 2.30 & 2.34 & & \\
\hline Price of daily gain, L.E & 4.387 & 5.502 & 5.842 & & \\
\hline Economical return, L.E per head/d & 2.237 & 3.202 & 3.502 & & \\
\hline Economic efficiency & 0.0204 & 0.0239 & 0.0259 & & \\
\hline Relative economic efficiency & 100 & 117 & 127 & & \\
\hline
\end{tabular}

a,b,c Means in the same row with different superscripts were different $(p<0.05)$.

${ }^{1}$ Control (lambs were fed $600 \mathrm{~g}$ of a concentrate feed mixture plus $400 \mathrm{~g}$ of rice straw per $\mathrm{kg}$ of DM without any probiotic); PP (control diet supplemented with $20 \mathrm{~g}$ of the probiotic in powder form per animal/day); and PL (control diet supplemented with $10 \mathrm{ml}$ of the probiotic in liquid form per animal/day) in a completely randomized block design.

${ }^{2} \mathrm{SEM}=$ greatest standard error of the mean.

${ }^{3}$ Economic efficiency = Price of average daily gain (L.E)/average daily feed cost (L.E). Calculated based on the following prices in Egyptian pounds (L.E.) per ton, 2015: Rice straw $=240$ L.E/ton., Commercial feed mixture $=2250$ L.E./ton. The price of one $\mathrm{kg}$ of body weight was $35 \mathrm{~L} . \mathrm{E}$.

enhanced $(p<0.05)$ with probiotics supplementation. Calculated feed cost was higher for probiotics treatments versus the control but returns, economic efficiency and relative economic efficiency were higher for the probiotics treatments.

\section{In vitro study}

Effects of addition of the probiotics product (i.e., PL and $\mathrm{PP}$ ) on in vitro gas production parameters, methane emission and protozoa count of diets are
Table 5. Effects of probiotic additives on in vitro ruminal dry matter and organic matter degradability (g degraded/g incubated), and gas and $\mathrm{CH}_{4}$ production, and protozoa populations in female barki sheep.

\begin{tabular}{lcccccc}
\hline & \multicolumn{3}{c}{ Treatment $^{1}$} & & \\
\cline { 2 - 4 } & Control & PP & PL & SEM $^{2}$ & $p$-Value \\
\hline Dry matter degradability & $0.45^{\mathrm{b}}$ & $0.48^{\mathrm{a}}$ & $0.48^{\mathrm{a}}$ & 0.006 & 0.009 \\
Organic matter degradability & $0.53^{\mathrm{b}}$ & $0.55^{\mathrm{a}}$ & $0.55^{\mathrm{a}}$ & 0.008 & 0.01 \\
Gas production, $\mathrm{ml} / \mathrm{g}$ of DM & $44.8^{\mathrm{b}}$ & $47.3^{\mathrm{a}}$ & $47.3^{\mathrm{a}}$ & 0.54 & 0.02 \\
$\mathrm{CH}_{4}, \mathrm{ml} / \mathrm{g}$ of DM & $9.3^{\mathrm{a}}$ & $8.1^{\mathrm{b}}$ & $8.1^{\mathrm{b}}$ & 0.71 & 0.02 \\
Protozoa, log count/mL & $5.0^{\mathrm{a}}$ & $4.1^{\mathrm{b}}$ & $4.2^{\mathrm{b}}$ & 0.52 & 0.03 \\
\hline
\end{tabular}

${ }_{\mathrm{a}, \mathrm{b}}$ Means in the same row with different superscripts were different $(p<0.05)$.

${ }^{1}$ Control (lambs were fed $600 \mathrm{~g}$ of a concentrate feed mixture plus $400 \mathrm{~g}$ of rice straw per $\mathrm{kg}$ of DM without any probiotic); PP (control diet supplemented with $20 \mathrm{~g}$ of the probiotic in powder form per animal/day) and PL (control diet supplemented with $10 \mathrm{ml}$ of the probiotic in liquid form per animal/day) in a completely randomized block design.

${ }^{2}$ SEM: greatest standard error of the mean.

shown in Table 5. Gas production was greater $(p<0.05)$ in probiotics diets compared with control diet. Methane emission and protozoa count were significantly less $(p<0.05)$ in the treated groups versus control group.

\section{Discussion}

Increased DM intake noted in the present study is consistent with a previous study, which reported greater DM intake of steers supplemented with multienzymes sourced from the same probiotic product. $^{2}$

Improvement of nutrient digestibility by addition of probiotics, especially the liquid form (i.e., PL) was probably due to the beneficial effects on fiber hydrolysis and rumen fermentation activity. ${ }^{1}$ Consistent with the present study, Deng et al. $^{24}$ reported greater apparent digestibility of $\mathrm{DM}, \mathrm{OM}, \mathrm{N}$ and NDF in Dorper wethers supplemented with Bacillus licheniformis. In contrast, Le et al. ${ }^{25}$ reported no differences in apparent digestibility of DM, OM and NDF in B. amyloliquefaciens supplemented ewes. Greater NDF digestibility with the addition of probiotics product rich in exogenous enzymes and bacterial cells may be due to greater ruminal degradability, which could reduce physical fill and allow greater DM intake. ${ }^{26}$ However, Nsereko et al. ${ }^{27}$ suggested that improved digestibility caused by exogenous enzyme supplement might be related to improved microbial colonization. Both enzyme forms improved colonization and increased activity of the exogenous enzyme within the rumen. ${ }^{5}$ This view is similar to previous hypotheses that exogenous enzymes increased fibrolytic activity due to increased numbers of ruminal microbes, and increased bacterial attachment and synergistic effects with hydrolysis of ruminal microorganisms. ${ }^{4}$ 
It is noteworthy that greater nutrient digestibility as a result of enzyme supplementation will result in improvement in nutritive value. This trend was noted in the present study with improvement in the diets supplemented with the probiotics. Dean et al. ${ }^{28}$ found that the nutritive value and fermentation of Bermudagrass silage can be improved by treating it with fibrolytic enzymes compared with control silages. This may be as a result of partial digestion of feed or weaken cell wall barriers that limit rumen microbial digestion. The direct action of exogenous enzymes before feed consumption can cause the release of reducing sugars arising from partial solubilization of cell wall components. This may, therefore, increase available carbohydrates in the rumen thereby shortening the lag time needed for microbial colonization and can also enhance rapid microbial attachment and growth. ${ }^{28}$ These factors reflect an increase in the hydrolytic capacity of the rumen, which indirectly reduces gut fill and hence enhances DM intake. ${ }^{26}$ Greater $\mathrm{N}$ intake and absorption in probiotics groups is in agreement with a previous study, which found $\mathrm{N}$ utilization improvements in tree fodder forages as a result of application of the exogenous fibrolytic enzyme preparation form. ${ }^{29}$

However, the low concentration of $\mathrm{NH}_{3}-\mathrm{N}$ and the greater amount of total VFA obtained with probiotics inclusion in the present study suggested that they could favor the carbon flow and VFA production. Consistent with this assumption, Le et al. ${ }^{25}$ reported lower ruminal $\mathrm{NH}_{3}-\mathrm{N}$ concentration for $B$. amyloliquefaciens supplemented ewes.

Probiotics product use can improve stimulation of ruminal microorganism activity by reducing $\mathrm{NH}_{3}-\mathrm{N}$ concentration in the rumen liquor by incorporation of $\mathrm{NH}_{3}-\mathrm{N}$ into microbial protein. ${ }^{1}$ This effect is attributed to an increase in microbial colonization of feed particles and that exogenous enzymes may act similarly to primary bacterial colonization. ${ }^{30}$ Gado et al. ${ }^{1}$ observed greater VFA production in lambs due to enhanced fiber digestibility of the diet. Increases in passage rate can be associated with a faster rate of particle size reduction in the rumen and a corresponding increase in feed intake. ${ }^{26}$

It is well known that microbial protein synthesis is a good indicator of beneficial effect of feed utilization. Microbial protein has the most significant impact on both quantity and quality of protein absorbed from the small intestine. Salem et al. ${ }^{31}$ indicated that the same probiotics product used in the present work increased the amount of microbial protein available for animal metabolism, which might be more efficient for enhancing fiber digestibility and consequently providing more nutrients for ruminal microorganisms beneficial for microbial growth. Feeding the enzyme preparation may have stimulated or increased total viable rumen bacterial numbers, or both, because rumen microbial $\mathrm{N}$ synthesis was increased, which may be partially due to greater fiber digestion or an improved capacity of rumen bacteria to digest feed.

Hirstov et al. $^{32}$ showed that enzymatic activities declined when two different exogenous fibrolytic enzyme products where administered directly into the rumen due to enzyme inactivation and passage of fluid from the rumen. Similarly, maximizing the proportion of the diet to which the enzyme is added is considered to increase the chances that the enzymes will remain active in the rumen. ${ }^{5}$

Improvement of the average daily gain, G:F and economic efficiency by addition of probiotics product (i.e., PP or PL) was probably due to the improvement in nutrient digestibility of the diets. Supplementing diets with probiotics product rich in enzymes and bacterial live cells has been shown to improve average daily gain and G:F of feedlot cattle. Salem et al. ${ }^{2}$ indicated that weight gain can be improved with the same probiotics product, although the response will vary as a function of the selected enzymes, doses and substrate.

Increasing level of fibrolytic enzymes increased rate and production of in vitro gas with some raw agricultural waste ${ }^{33}$ or total mixed rations of different roughage concentrate ratios. ${ }^{34}$ Colombatto et al. ${ }^{4}$ reported short-term effect of enzymes on the degradation of feeds, with limited effects during fermentation. This continuous effect might be partly due to the pre-incubation effect that may form stable enzyme-feed complex.

Methane production reduction may be related to microflora change of methanogenium leaded by enzyme addition. ${ }^{35}$ In an in vivo study undertaken by Deng et al., ${ }^{24}$ methane production was reduced by $6 \%$ in wethers supplemented with $2.5 \times 10^{8} \mathrm{CFU}$ of $B$. licheniformis per head per day. Consistent with the present study, they reported higher concentration of propionate and lower concentration of acetate. It is known that propionate production is an alternative hydrogen sink, which competes with methanogens for available hydrogen. ${ }^{36}$ Therefore, increases in propionate concentration is likely to result in a reduction in methane production with concomitant decrease in acetate concentration. ${ }^{36,37}$ Acetate production is associated with the release of $\mathrm{H}_{2}$, which can be used by methanogenic bacteria to form methane. ${ }^{30}$ However, only a few studies have 
investigated effects of exogenous enzymes on methane production and results are conflicting. ${ }^{24,38}$

\section{Conclusion}

Results showed that the probiotics product preparations used in the present enhanced nutrient intake and nutrient digestibility with concomitant increase in animal performance. Additionally, the probiotic products reduced both $\mathrm{NH}_{3}-\mathrm{N}$ and methane production but increased VFA concentration and microbial nitrogen yield.

\section{Disclosure statement}

All authors declare that there are no present or potential conflicts of interest among the authors and other people or organizations that could inappropriately bias their work.

\section{ORCID}

Abdelfattah Z. M. Salem (D) http://orcid.org/0000-0001$7418-4170$

\section{References}

1. Gado HM, Salem AZM, Odongo NE, Borhami BE. Influence of exogenous enzymes ensiled with orange pulp on digestion and growth performance in lambs. Anim. Feed Sci. Technol. 2011;165(1-2):131-136.

2. Salem AZM, Gado HM, Colombatto D, Eghandour MMY. Effect of exogenous enzymes on nutrient digestibility, ruminal fermentation and growth performance in beef steers. Livest Sci. 2013;154(1-3): 69-73.

3. McAllister TA, Beauchemin KA, Alazzeh AY, Baah J, Teather RM, Stanford K. Review: the use of direct fed microbials to mitigate pathogens and enhance production in cattle. Can J Anim Sci. 2011;91(2):193-211.

4. Colombatto D, Mould FL, Bhat MK, Owen E. Influence of exogenous fibrolytic enzyme level and incubation $\mathrm{pH}$ on the in vitro ruminal fermentation of alfalfa stems. Anim. Feed Sci. Technol. 2007; 137(1-2):150-162.

5. Beauchemin KA, Colombatto D, Morgavi DR, Yang WZ, Rode LM. Mode of action of exogenous cell wall degrading enzymes for ruminants. Can J Anim Sci. 2004;84(1):13-22.

6. Gado HM, Elghandour MMY, Cipriano M, Odongo NE, Salem AZM. Rumen degradation and nutritive utilization of wheat straw, corn stalks and sugarcane bagasse ensiled with multi-enzymes. J Appl Anim Res. 2017;45(1):485.

7. Ohya T, Marubashi T, Ito H. Significance of fecal volatile fatty acids in shedding of Escherichia coli O157 from calves: experimental infection and preliminary use of a probiotic product. J Vet Med Sci. 2000;62(11):1151-1155.

8. Krehbiel CR, Rust SR, Zhang G, Gilliland SE. Bacterial direct-fed microbials in ruminant diets: performance response and mode of action. J Anim Sci. 2003;81:120-132.

9. Gado HM, Salem AZM. 2008. Influence of exogenous enzymes from anaerobic source on growth performance, digestibility, ruminal fermentation and blood metabolites in lambs fed of orange pulp silage in total mixed ration. In: 59th Annual Meeting of the European Association for Animal Production, Vilnius, Lithuania, August 24-27, p. 228.

10. Patra AK. The use of live yeast products as microbial additives in ruminant nutrition. Asian $J$ of Animal and Veterinary Advances. 2012;7:366-375.

11. NRC. Nutrient Requirements of Sheep. Academy of Sciences. Washington, DC: National Research Council; 2007.

12. AOAC, Association of Official Analytical Chemists. Official Methods of Analysis. 16th ed. Arlington, VA: AOAC; 1997.

13. Van Soest PJ, Robertson, JB, Lewis, BA, Methods for dietary fiber, neutral detergent fiber and non-starch polysaccharides in relation to animal nutrition. J Dairy Sci. 1991;74:3583-3597.

14. Rinne M, Jaakkola S, Huhtanen P. Grass maturity effects on cattle fed silage-based diets. 1. Organic matter digestion, rumen fermentation and nitrogen utilization. Anim Feed Sci Tech. 1997;67(1):1-17.

15. Al-Rabbat MF, Baldwin RL, Weir WC. In vitro nitrogen-tracer technique for some kinetic measures of rumen ammonia. J Dairy Sci. 1971;54(8):1150-1161.

16. Warner ACI. Production of volatile fatty acids in the RUMEN: METHODS OF MEASUREMENT. Nutr Abstr Rev. 1964;34:339-352.

17. Borhami BE, Fahmay WG, El-Shazly K. 1992. Rumen environment, microbial protein synthesis and nitrogen balance in sheep. A proceeding of manipulation of rumen microorganisms. In: Borhami BE, El-Shazly K, eds. International Conference on Manipulation of Rumen Microorganisms to Improve Efficiency of Fermentation and Ruminant Production. Egypt, September 20-23. pp: 138-144.

18. Walker DJ. Energy metabolism and rumen microorganisms. In: Daughery LRW, ed. Physiology of digestion in the ruminant. Washington, DC: Butterworth Inc; 1965.

19. Hungate RE, ed. The Rumen and Its Microbes. New York: Academic Press; 1965:533.

20. Theodorou MK, Williams BA, Dhanoa MS, McAllan $\mathrm{AB}$, France J. A simple gas production method using a pressure transducer to determine the fermentation kinetics of ruminant feeds. Anim Feed Sci Technol. 1994;48(3-4):185-197.

21. Dehority BA. Rumen Microbiology. Nottingham, UK: Nottingham University Press; 2003.

22. SAS. Statistical Analysis System. User's Guide: Statistics. Ver 9.0. Cary, NC: SAS Institute; 2002.

23. Udén P, Robinson PH, Mateos GG, et al. Use of replicates in statistical analyses in papers submitted for 
publication in Animal Feed Science and Technology. Anim Feed Sci Technol. 2012;171:1-5.

24. Deng KD, Xiao Y, Ma T, et al. Ruminal fermentation, nutrient metabolism, and methane emissions of sheep in response to dietary supplementation with Bacillus licheniformis. Anim Feed Sci Technol. 2018;241:38-44.

25. Le OT, Schofield B, Dart PJ, et al. Production responses of reproducing ewes to a byproduct-based diet inoculated with the probiotic Bacillus amyloliquefaciens strain H57. Anim Prod Sci. 2017;57(6):1097-1105.

26. Kazemi-Bonchenari M, Salem AZM, López S. Influence of barley grain particle size and treatment with citric acid on digestibility, ruminal fermentation and microbial protein synthesis in Holstein calves. Animal. 2017;11(8):1295-1302.

27. Nsereko VL, Beauchemin KA, Morgavi DP, et al. Effect of a fibrolytic enzyme preparation from Trichoderma longibrachiatum on the rumen microbial population of dairy cows. Can J Microbiol. 2002;48(1): 14-20.

28. Dean A, Adesogan T, Krueger N, Littell RC. Effect of fibrolytic enzymes on the fermentation characteristics, aerobic stability, and digestibility of Bermudagrass silage. J Dairy Sci. 2005;88(3):994-1003.

29. Salem AZM, Hassan AA, Khalil MS, Gado HM, Alsersy $\mathrm{H}$, Simbaya J. Effects of sun-drying and exogenous enzymes on nutrients intake, digestibility and nitrogen utilization in sheep fed Atriplex halimus foliages. Anim Feed Sci Technol. 2012;171(2-4):128-135.

30. Stewart CS, Flint HJ, Bryant MP. The rumen bacteria. In: Hobson PN, Stewart CS, eds. The Rumen Microbial Ecosystem. London, UK: Chapman and Hall; 1997:10-72.

31. Salem AZM, Alsersy H, Camacho LM, et al. Feed intake, nutrient digestibility, nitrogen utilization, and ruminal fermentation activities in sheep fed Atriplex halimus ensiled with three developed enzyme cocktails. Czech J Anim Sci. 2015;60:185-194.

32. Hristov AN, Rode LM, Beauchemin KA, Wuerfel RL. Effect of a commercial enzyme preparation on barley silage in vitro and in sacco dry matter degradability. Proc West Sect Am Soc Anim Sci. 1996;47:282-284.

33. Kholif AE, Elghandour MMY, Rodríguez GB, Olafadehan OA, Salem AZM. Anaerobic ensiling of raw agricultural waste with a fibrolytic enzyme cocktail as a cleaner and sustainable biological product. J Cleaner Prod. 2017;142:2649-2655.

34. Elghandour MMY, Kholif AE, Hernández A, Salem AZM, Mellado M, Odongo NE. Effects of organic acid salts on ruminal biogas production and fermentation kinetics of total mixed rations with different maize silage to concentrate ratios. J Cleaner Prod. 2017;147:523-530.

35. Zhou M, Chung $\mathrm{YH}$, Beauchemin $\mathrm{KA}$, et al. Relationship between rumen methanogens and methane production in dairy cows fed diets supplemented with a feed enzyme additive. J Appl Microbiol. 2011;111(5):1148-1158.

36. Tapio I, Snelling TJ, Strozzi F, Wallace RJ. The ruminal microbiome associated with methane emissions from ruminant livestock. J Anim Sci Biotechnol. 2017; 8:7-17.

37. Seo JK, Kim S-W, Kim MH, Upadhaya SD, Kam DK, Ha JK. Direct-fed microbials for ruminant animals. Asian Australas J Anim Sci. 2010;23(12):1657-1667.

38. Hernández A, Kholif AE, Elghandour MMY, et al. Effectiveness of xylanase and Saccharomyces cerevisiae as feed additives on gas emissions from agricultural calf farms. J. Cleaner Prod. 2017;148:616-623. 